\title{
DECREASING THE “BAD” FOR MIXED PUBLIC GOODS AND BADS:
}

\section{THE CASE OF PUBLIC SCULPTURE}

\author{
Joseph J. Cordes \\ George Washington University \\ and \\ Robert S. Goldfarb \\ George Washington University
}

A standard analysis in public economics involves the provision of a public good, and how much of that good it is desirable to provide. A related standard analysis considers the problem of regulating a public bad, such as pollution. What is not usually considered is a class of public products that are both public goods and public bads: products that produce positive utility for some, and negative utility for others "forced" to experience them. Some might argue that expenditures on national defense sometimes fit this characterization; others might see the reintroduction of wolf populations into US national parks as fitting it. Whatever one's reaction to these possible examples, however, it seems clear, as we will argue below, that the example of controversial public sculpture does fit the mixed public good-public bad characterization.

This paper considers the following issue: when confronted with a mixed public good/public bad, what are the "economic design" options for decreasing the negative utility generated relative to the positive utility produced? Or, to state the issue more flamboyantly, are there ways to help insure that public goods are not also serious public bads? Because it is both difficult and seemingly unrewarding to tackle this economic design question in the abstract, we apply our analysis to the concrete example of controversial public sculpture.

The later part of this paper sets forth some instructive specific controversies involving the provision of public sculpture in the United States. First, we present a simple public goods-bads framework that helps us analyze the economic design issues that arise in the controversial public sculpture setting.

\section{THE SIMPLE ECONOMICS OF MIXED PUBLIC GOODS/BADS IN THE PUBLIC SCULPTURE CONTEXT}

Consider a large-scale sculpture placed prominently in a public location. Anyone compelled to visit that location must view this sculpture, so that the installation is a

Robert S. Goldfarb: Department of Economics, George Washington University, 1922 F Street NW, Washington, D.C. 20052. E-mail: gldfrb@gwu.edu. 
non-excludable local public "good." Once provided to one person, others in that location must also view ("consume") it. There are numerous well-known cases in which some of those compelled to view particular public sculptures were offended by it (while others enjoyed that same experience). Such works of art are public goods to some viewers, and public bads to others.

\section{Controversial Art and Small Numbers}

To better appreciate the economic design options available for affecting the "good/ bad mix" associated with controversial public art, it is useful to first analyze a small numbers case, then see how things change as we move to a large numbers case.

How might rational economic actors in a small numbers situation respond to the placement of a controversial work of visual art? Consider in particular a two-person household that wants to purchase a piece of art--say, a painting--for the living room. Suppose that household member $\mathrm{H} 1$ finds a painting he or she really likes that at the same time is greatly disliked by the other household member H2--"I won't have that thing in our living room."

While this painting is a "local (living room) public good" for individual H1, it is a "local (living room) public bad" for individual H2. Yet if the relationship in question is successful, this taste disagreement is likely to be resolved by negotiation, rather than generating continuing controversy. Both parties might (1) agree to look for some other painting, or (2) put the painting in H1's home office. Either option reduces or eliminates the disutility to spouse $\mathrm{H} 2$ engendered by the (local) public bad, perhaps with some reduction in viewing benefits for spouse H1. Alternatively, (3) H2 could agree to accept the painting in return for renovating a portion of the house to his or her taste; that is, accept a side payment to compensate for disutility suffered.

Figure 1 shows how these issues can be represented in a simple model of public goods provision. For expository purposes, we first portray a good available in infinitely and continuously divisible units, rather than one available only in integer units. The horizontal axis measures units of some potentially controversial public good. The schedule bb is the marginal valuation of those who benefit from consuming the good, mc is the marginal cost of providing the good (assumed constant for simplicity), and dd represents the marginal disutility costs (in dollars) imposed on those who must consume the good they dislike.

The schedule bc in Fig. 1 represents the net community benefits from differing levels of the controversial public good. It is derived by vertically summing the marginal benefit schedule bb and the marginal disutility schedule dd. The implication is that overall net well-being in the community would be at a maximum if an arrangement could be found to provide $\mathbf{G}^{*}$ units of the controversial public good, with those who benefit from its consumption paying both the direct costs associated with its provision ( the area $\mathbf{\$ 0 \mathbf { a e G }} *$ ) and indirect costs or side-payments equal to the area $\mathbf{d G} * \mathbf{f}$ needed to compensate those forced to consume the public good.

In the case of our painting, available only in the integer unit $G=1$, one would evaluate the bb and dd values at $G=1$. Subtracting the dd from the bb value would generate the bc value - the "net community benefits" of providing the painting. If that bc value was greater than the mc of providing it, the implication is like the one in the 
previous paragraph: overall net well-being in the household would be increased by providing the painting, assuming an appropriate assignment of direct and indirect costs.

FIGURE 1

Provision of a Mixed Public Good/Public Bad

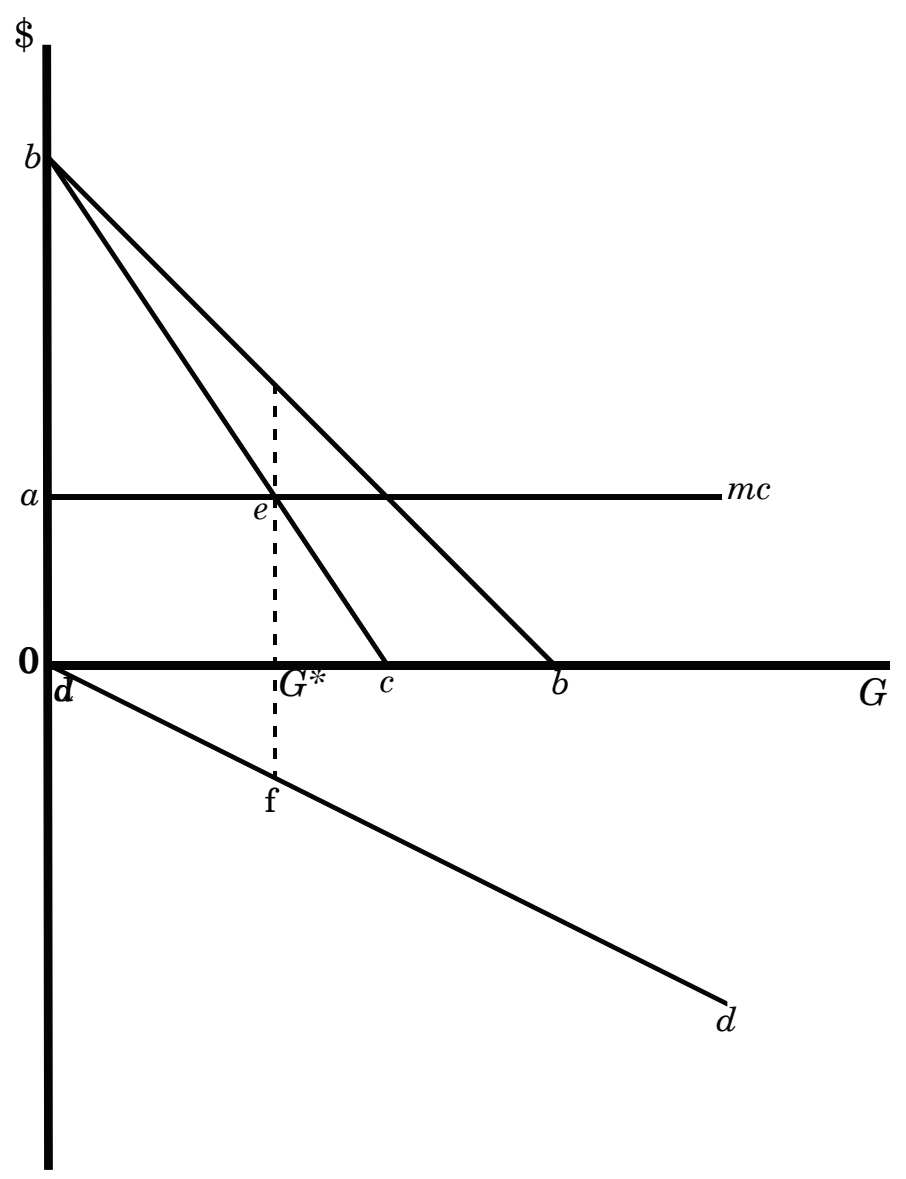

One can complicate Figure 1 in various ways: increasing marginal disutility as $\mathrm{G}$ rises, rising marginal cost of production, starting the marginal disutility schedule dd below zero, and so forth. However, the two basic implications of Figure 1 would not change. First, maximizing net benefits requires the beneficiaries to compensate those who get disutility from the forced consumption of G. Second, "gains from trade" (e.g., between those who view G as a "good" and those who treat it as a "bad") are possible in principle.

\section{Bargaining, Negotiation, and the Large Numbers Case}

The above analysis strongly suggests that the collective consumption attributes of a controversial work of art need not provoke continuing disagreement and utility 
losses, provided that there are arrangements that facilitate welfare-enhancing negotiation between parties that would otherwise be forced to jointly consume a mixed public good and public bad. Negotiation, perhaps leading to side-payments, is feasible when the number of affected parties is small, as in a household. Achieving a similar negotiated settlement is highly unlikely, however, in the large group setting of public sculpture. The competing and largely unknown tastes of thousands of unidentified potential consumers may be involved. Even if the relevant consumers could be identified, a "negotiation among thousands," analogous to the two-party household communication, is hard to imagine. Not only is the number of affected parties quite large, but there are no longstanding personal relationships that make successful negotiation far more likely.

This raises the economic design issue that is the focus of this paper. ${ }^{1}$ Given these difficulties with applying the small-numbers solution to the large-group setting of many public- sculpture installations, are there methods of provision that can lessen the utility losses that the controversy being generated suggests? That is, in the public sculpture case, is it possible to alter the mix of public good to public bad by choice of provision method? To address this question, it is necessary to first describe some instructive public sculpture controversies.

\section{SOME ILLUSTRATIVE PUBLIC ART CONTROVERSIES}

\section{The "Tilted Arc" Case}

One particularly famous and very telling case involves Richard Serra's sculpture, “Tilted Arc." The case highlights important issues, and has elicited comments and analysis from art historians and arts policy analysts. At least three entire books [American Council for the Arts, 1989; Weyergraf-Serra and Buskirk, 1991; Senie 2002] are devoted solely to the controversy. Much of this controversy seems to have arisen because people not predisposed to appreciate this sculpture were forced to confront it as part of their daily routine.

The details are as follows. Serra, a distinguished contemporary sculptor, ${ }^{2}$ was commissioned by the General Services Administration (GSA) to provide a sculpture for the plaza in front of New York City's Jacob Javits Federal Office Building, "an anonymous and really ugly very large structure from the 1960's" [Glazer 1992, 10; see also Senie, 2002, 89]. Put in place in 1981 at an initial outlay cost of $\$ 175,000$, the piece generated immense and continuing controversy, resulting in pressure to have the sculpture removed. Following GSA hearings, litigation, and so forth, the sculpture was dismantled 9 years after its installation. ${ }^{3}$

Why all the controversy? Putting in the sculpture, entitled "Tilted Arc," "obstructed the plaza,.offered no space to sit on,...blocked sun and view, and made the plaza unusable even for those moments of freedom when the weather permitted office workers to eat their lunch outside" (Glazer,1992,13]. The sculpture itself, an arc-shaped wall constructed of CorTen steel (which has the appearance of rusted iron) 120 feet long and 12 feet high, seemed to prevent anyone from directly crossing the plaza; walkers had to go around the rather extensive new installation. It "challenged the illusion of personal freedom by seeming to curtail movement...At the same time, by obscuring 
the sense of unobstructed vision in Federal Plaza, Tilted Arc threatened the fragile illusion of personal safety." [Senie, 2002, 94]. ${ }^{4}$

An interesting feature of this case involves Serra's intentions in creating the sculpture; Glazer uses published interviews with Serra to illuminate what Serra apparently intended. Serra's position appears to be that much of modern architecture is awful, and one function of public sculpture is to "subvert the context" (Serra's own phrase), to further emphasize the awfulness of the architecture it embellishes. "He was building something large and permanent...a permanent critique...He is attacking the awful by increasing the awfulness." [Glazer, 1992, 13].

This description is certainly consistent with the idea that the sculpture was intended to discomfort and irritate those confronting it, an aim it appears to have succeeded spectacularly in attaining. So if the Glazer account is a correct rendition of Serra's aims, it is hardly surprising that the sculpture did in fact irritate some of those forced to view it.

Senie has a different and more complex take on what Serra might have been up to. ${ }^{5}$ She quotes a Serra statement of 1980 about Tilted Arc:

Placing pieces in an urban context is not synonymous with an interest in a large audience...The work I do does not allow for experience outside the conventions of sculpture as sculpture. My audience is necessarily very limited.

She goes on to say: "Serra was clear. He considered the general public only as figures moving through the space, distinct from his true audience, an art audience." [Senie, 2002,41]. ${ }^{6} 7$

The Tilted Arc case may seem idiosyncratic, but it is actually viewed as a central and crucial episode by art historians who are students of public sculpture. For example, Senie and Sally Webster [1992] observe that "Indeed, the controversy surrounding Serra's Tilted Arc, contemporary with Lin's [Vietnam] memorial, encapsulated the problems of monolithic abstract sculpture in the public domain. Issues regarding the selection process, as well as the nature of good public art, are still being debated today" [Senie and Webster, 1992, xv]. ${ }^{8}$

\section{The Serra Example is not Unique}

The "sculpture as public irritant" phenomenon does not begin or end with Serra. Numerous other public sculptures, not necessarily intended to discomfort viewers, have also generated public controversy. Writing in 1982, long before the Serra drama had fully unfolded, Stalker and Glymour [1982] cite works by Andre, Sugarman, Ginnevar, and di Suvaro, among others, as creating uproars, "not simply because the public objected to paying for the works, but because significant segments did not want the objects publicly displayed in the settings in which they...were...thrust." [Stalker and Glymour, 1982, 6].

A more recent episode provides an instructive counterpoint to the Serra example, in that it illustrates the fact that public sculpture need not be designed to irritate in order to generate public controversy. In the wake of the Oklahoma City bombing, the 
Federal Marshal in charge of security at a Federal courthouse in Baltimore, Maryland declared that a sculpture in front of that building was a security hazard. The sculpture, by George Sugarman, had been installed in 1978, almost two decades earlier. The Marshal argued that a bomb might be hidden inside the sculpture. The bomb's explosion would "have the same effect as a hand grenade," doing "horrible damage to people outside the building," and "could penetrate the building as well."

What is noteworthy about this episode is the reaction of those frequenting the building to the Marshal's argument. As reported in the Washington Post [Valentine, 1995], many individuals expressed the view that the sculpture ought to be removed because it was an objectionable eyesore rather than a security risk:

The sculpture stirred controversy from its inception, with near-solid opposition from judges and others using the courthouse. It continues to be the butt of wry remarks from lawyers. "It may be a security hazard today," said...a former chief prosecutor..."but it was a hazard to the eyesight long before Oklahoma City,”...(A) criminal defense lawyer... said its removal "would be a public service"[Valentine,1995,B-3].

Sugarman, unlike Serra, designed this sculpture to appeal to viewers, not to irritate them. It is brightly multicolored and playful, reminiscent in some ways of very attractive children's playground equipment. The Post article describes it as "a series of large aluminum plates welded together in a latticework of seats and bower-like overhangs painted in bright blues, oranges, greens and reds." Sugarman is quoted in the article about his intentions in building the sculpture:

My whole point...was to make a social place that people could participate in....reflective of the open democracy that a courthouse is supposed to represent in this country...It's a very idealistic piece.

Illustrative of the point that one person's bad is another person's good, one of the authors, upon seeing the Sugarman, found it hard to understand the negative reactions to it. It seemed to him to liven up the otherwise very dull appearance of a rather plain office building and its unprepossessing entrance.

These examples support the proposition that public sculpture installations have the potential to be mixed public goods and bads. This suggests the economic design question: are there methods of provision that might alter the "good/bad" $\mathrm{mix}$ ? And if there are, do those design options themselves contain hidden costs? The next section considers these issues.

\section{THE "ECONOMIC DESIGN" ISSUE: CAN THE "PUBLIC GOOD/PUBLIC BAD” MIX BE ALTERED? AND IS THE “CURE" WORSE THAN THE "DISEASE?"}

The economic analysis of the "small numbers" case presented above suggested that negotiation might be used to offset the disutility generated by an economic bad. It seems likely that the type of bargaining that can take place in small groups is not 
feasible in the face of large numbers. There is, however, an economic design question for the large numbers case: are there administratively feasible ways of dealing with public art controversies that at least partially "mimic" some of the outcomes identified in the small numbers case. There appear to be at least four broad strategies for achieving this result. One is to devise procedures for public sculpture provision that introduce a measure of "bargaining" between those for whom (nonexcludable) consumption of the public sculpture is a public good, and those for whom it is a public bad. A second strategy is to modify the placement of the sculpture so as to make its "publicness" less extensive. A third possibility is to modify the attributes of the public sculpture to reduce the negative utility experienced by those who cannot be excluded from consuming it, and view such forced consumption as a public bad. A fourth possibility involves providing information intended to influence viewer reactions to particular sculpture installations.

\section{The Selection Process: Creating Opportunities for Negotiation}

Even when literal "bargaining among thousands" is not feasible, the administrative and political process that is used to select public sculpture can be structured to approximate negotiation to some extent. Hindsight suggests that the controversy over Serra's Tilted Arc might have been avoided or defused if effective representation of the plaza's "users" had been included in the selection process. Presumably, effective representation would have resulted in a different (or modified) design being selected. More broadly, including community representatives in the process for selecting placement of the sculpture holds the potential for lessening Serra-like controversies after the sculpture is installed. ${ }^{9}$

In terms of Figure 1, negotiation has the potential of shifting up the dd curve, so that those potentially discomfited by the sculpture installation are less negatively affected. This in turn raises the bc curve (the net benefits from providing the sculpture). The interpretation for the discrete (integer only) case is straightforward.

An illustration of the positive effect of "community involvement" involves two "similar" sculptures by the well-known sculptor, George Segal. One sculpture, in Youngstown, Ohio, in front of the City Hall, portrays steelworkers, and was done with considerable community participation. For example, "the sculpture commemorates two workers who were in fact nominated by co-workers....Segal himself said that it was the first time in over twenty years that so many other people's attitudes and decisions had been involved in his work." [Fleming, 1982, 28-29]. This work is apparently very popular, and both Fleming [1982] and Stalker and Glymour [1982] describe it approvingly.

Another work by the same artist, involving a statue of restaurant workers in Buffalo, was not as well-received. Art critics described it as "plainly ill-suited and illplaced outside the Federal Building in Buffalo, New York" [Stalker and Glymour, 1982, 17]. One issue was that the statue did not represent Buffalo concerns and traditions in the same way as the steelworker piece represented these items in Youngstown. The Buffalo commission "did not include the same involvement" by the community [Fleming, 1982, 29]. 
An interesting attempt to solicit potential viewer opinions about proposed public art took place in Vancouver, British Columbia in the spring and summer of 2000. Vancouver's art museum attempted to gauge viewer opinion about eight proposals for public art. Three of the eight were to be acquired and installed outside the museum or in the gallery itself. The museum displayed the designs for the eight proposals in a display case on a main street (with lots of pedestrian traffic) in front of a museum entrance. Two of the eight proposals were displayed at a time, each for a little more than 3 weeks. Forms were provided which asked those viewing the designs for their reactions. There was also a phone-in hotline and e-mail address for sending in reactions, and Gallery staff were available at the display case at selected times to take verbal reactions. As one of the information cards provided for viewers put it, "The public presentation of these proposals is intended to initiate a dialogue with the business people, shoppers, gallery visitors, students, tourists and others who move about the Gallery grounds every day."

The selection procedure just described does not perfectly mimic the two-person household negotiation. Notably, it does not give the viewers any explicit participation in the actual acquisition decision. It does, however, provide potential viewers of the final product some "voice"--some way to allow their opinions to be heard by the actual decision-makers. The example illustrates the proposition that selection mechanisms can be designed to allow potential viewers some way to participate in the process of choosing public art installations. Such opinion feedback can potentially operate to diffuse controversy by affecting actual selection. ${ }^{10}$

\section{Placement Choices Reducing the Sculpture's "Publicness"}

A controversial public sculpture can also be made into less of a public bad by placing or displaying the work so as to exclude from its consumption those who find the work offensive. Here again, as in the previous "negotiation" discussion, the effect on Figure 1 is to shift up (lessen the negative dimension of) the dd curve, which in turn raises the bc curve (the net benefits from providing the sculpture). The difference between the two cases is in the reason the dd curve is shifting up. In this sculpture placement case, it is shifting up because fewer negatively affected individuals are experiencing the "bad." By contrast, in the negotiation case, the number of viewers is not affected, but the "disutility per viewer" is potentially reduced.

Two examples suggest that sculpture placement decisions can have an important influence on the level of controversy. The first involves the Vietnam Veterans Memorial (VVM). Why does the VVM seem to be much more widely accepted than Serra's Tilted Arc? To be sure, the VVM's initial reception did provoke considerable debate and complaint, but in recent years it seems to have been widely accepted and praised. ${ }^{11}$

Now one can think of numerous possible explanations for this more positive reaction to the VVM. Perhaps its design is simply "better," or at least more appealing, than sculptures such as Serra's. The VVM design was certainly chosen by what appears to be a far more rigorous and demanding competitive process than the one that selected Serra's. ${ }^{12}$ Or perhaps its status as a memorial shields it from excessive controversy of the Serra/Sugarman sort. Even more specifically, perhaps the listing of names on 
the memorial shields it from reactions that it is "overly modernist/abstract." Or perhaps the addition of some realistic figures of soldiers in response to early controversy ameliorated complaints?

While these and other factors may play a part, we want to emphasize the importance of the memorial's placement, which in turn affects its degree of exposure to the public. Public sculpture is a local public good/bad; one must be in geographical proximity to the sculpture to experience it. The physical placement of a sculpture can influence both the volume and especially the "mix" of individuals who actually see it. In particular, some placements will maximize the number of "innocent passers-by" forced to experience the sculpture, while other placements will insure that only those whose aim is to actually experience the sculpture will see it. Put differently, some placements will raise the volume of "bads" generated, while others will minimize that volume.

Whereas Serra's Tilted Arc was placed in a public plaza virtually unavoidable to those using the buildings surrounding the plaza, the VVM's location is such that most of those viewing it have gone in search of it. That is, its location is "isolated" in the sense that most of the pedestrian traffic in sight of the VVM are tourists investigating the Washington D.C. Mall and its monuments. This "isolation" is ensured by its placement on the Mall (as opposed to being placed in front of a downtown office building), but it is further guaranteed by its own design features. As Griswold [1986] points out, unlike virtually all of the older major Washington D.C. memorials, "the VVM is invisible from a distance, particularly as one approaches it from the north... It demands that you enter its space or miss it altogether" [Griswold, 1986,705-706].

In short, a "self-selection device" is in force to choose viewers of the VVM, whereas no such self-selection device applied to Serra's Tilted Arc. This self-selection device works to ensure that most of those who view the VVM are people who want to view the VVM. Even though public sculpture is a local public good/bad, its precise placement can affect the mix of viewers. In particular, some locations may help to "self-select" viewers who find sculpture to be a public good rather than a public bad.

Our second example illustrates the importance of placement using one of Serra's other sculptures, entitled Waxing Arc. This work is located in Rotterdam's Boymansvan Beuningen Museum, and dates from the same period as Tilted Arc (Waxing Arc is dated 1980; Tilted Arc was installed in 1981). Waxing Arc appears to be very similar to Tilted Arc. ${ }^{13}$ It is as though Tilted Arc had been sliced in half, and the two halves placed in the enclosed entrance to the museum. These two halves function as a very effective entrance corridor, channeling the visitor who passes through the museum's outer doors towards the museum's admission desk.

Since Waxing Arc is itself entirely inside the entrance room of the museum, no one is forced to view it who has not already entered the museum. The sculpture is in a closed space "behind a wall" and those not entering the museum are excluded from confronting the sculpture. Thus, no one is forced to experience this sculpture who does not volunteer to enter the museum. Since those choosing to enter museums are a group self-selected for their willingness to be "confronted" by (sometimes controversial) works of art, it is not surprising that this sculpture has not turned into the controversial cause celebre that Tilted Arc became. 
One possible reaction to all this, of course, might be that, by putting the Serra in a museum, or otherwise self-selecting the audience to limit viewers to those favorably predisposed, one is limiting or even destroying the notion of public art. If, for example, a Serra is put in a museum, "the pre-selected audience is an art audience and the work is defined as art by its presence in or around a museum." ${ }^{14}$

\section{Temporary vs. Permanent Sculpture Installation}

When exclusion is not possible, either for technical or aesthetic reasons, the negative impact on those forced to consume what they perceive to be a public bad will be affected by the permanence or lack thereof of the sculpture installation. One feature that makes a sculpture installation so seemingly momentous is its expected permanence. If one dislikes a newly-installed sculpture, and expects to be confronted by it every day for many years, the negative reaction --and therefore the potential for serious controversy--is likely to be much larger than if the installation is explicitly temporary, to be gone in (say) two months. Temporary sculpture installations therefore have the potential to provide considerable benefits, in terms of the ability to experience particular pieces of sculpture, to those for whom sculpture is a public good, while limiting the harm to those who dislike such sculpture..$^{15}$

In terms of Figure 1, making the installation temporary shifts up the dd curve, thereby lessening disutility, but it also shifts down the bb curve, lessening the utility of those who view the sculpture as a public good. It does both of these things by decreasing the future stream of consumption from the installation by cutting that stream off. Only if the (dollar value of) the decrease in disutility exceeds the decrease in utility does making the installation temporary seem attractive on economic design grounds. That is, only if the bc curve rises is this approach attractive. A "diminishing marginal utility of the public good/increasing marginal disutility of the public bad" argument can be asserted in support of the plausibility of a rise in bc. ${ }^{16}$

The above argument for temporary installations, consistent with the general mindset of this paper, focuses on the well-being of the willing or unwilling consumeras-viewer. A quite different argument for temporary installations focuses on concerns internal to the arts rather than on consumers. The arts commentator Patricia Phillips [1992] suggests that “ $(\mathrm{O})$ ne way that artists and agencies can continue to generate public art and remain analytical about its purpose, its composition, and how it is to be distinguished (or not) from other creative enterprises is to support more short-lived experiments in which variables can be changed and results...examined. Public art requires a more passionate commitment to the temporary..." [Phillips, 1992, 297].

The reader may wonder about the viability of temporary installations, given the expected costs of moving and installing large scale public sculpture. But, despite these seemingly large potential transactions costs, two types of temporary installations do in fact exist: "curated shows," and "sculptures designed to be temporary."

Curated Shows. Curated shows are like museum shows in that they are of fixed duration, sometimes showing a sizable selection of an artist's work. One example is a traveling exhibit of Fernando Botero sculptures that has appeared in outdoor public spaces in Paris, New York and Washington, D.C., to considerable acclaim [see Lewis, 1996]. Another example is an installation organized by New York's Public Art Fund 
of thirteen of Keith Haring's large scale sculptures along New York's Park Avenue between 53rd and 74th Street from June to October 1997. ${ }^{17}$ In the summer of 2000, with the cooperation of the Public Art Fund, a Jeff Koons sculpture entitled "Puppy," a "43 foot tall flower-covered sculpture in the shape of a West Highland terrier," appeared at New York's Rockefeller Center, remaining there until September 5 [Smith, 2000, B27]. ${ }^{18}$ The Botero, Haring, and Koons examples show that temporary installations are possible, and suggest the analogy to traveling and "temporary" museum shows. ${ }^{19}$

An interesting recent innovation involves cooperation between the Public Art Fund, the New York City Department of Parks and Recreation, and the Central Park Conservancy [Vogel, 2002]. Previous proposals to place art in New York's Central Park were frequently turned down. However, in February 2002 a series of sculpture installations commissioned by the Public Art Fund, and part of the Whitney Museum's Biennial, were placed in Central Park. The display was to be explicitly temporary, which was essential to obtaining the cooperation of the Parks Department and the Conservancy. As the director of the Public Art Fund put it, "Permanence is our enemy. We'd put ourselves out of business. We're creating a dialogue for our generation. These are works of art that remain in the imagination, and that's better than having the city cluttered with monuments" [Vogel, 2002, A23].

Sculptures designed to be temporary. Sculpture commissions can be offered that involve designing and installing sculptures meant to be temporary. George Washington University has commissioned several such sculptures, and Public Art Fund-sponsored installations are often explicitly temporary. ${ }^{20}$ Patricia Phillips [1994] identifies temporary art instances associated with the following organizations: Public Art Fund, Sculpture Chicago, Creative Time (in New York City), Forecast Public Artworks (Minnesota), and Public Art Works (California).

The work of Christo provides a notable example of this phenomenon. His well-known public art installations may be considered "bads" by some observers, but whatever negative reactions the installations may cause is surely diminished by the fact that his work is explicitly temporary. Each installation has a prearranged removal date. ${ }^{21}$

The same New York Times article that describes the Koons sculpture contains an implicit testimonial to our point that temporary installations may limit potential controversy. That article discusses a number of sculpture installations besides the Koons Puppy, some of distinctly questionable artistic merit. After discussing some of the specific displays, Smith[2000] asserts that:

It doesn't pay to think about them too much... At least... [they are]... temporary, unlike the parade of unimaginative buildings that are allowed to go up each year...(I)t is 'a supposedly fun thing' that, one hopes, the city will never do again. [Smith, 2000, B27]

In short, temporary means it will be gone soon, and need not be repeated.

\section{The Style-Choice Factor: Modifying Tastes}

Several of the above remedies involve modifying the character of the public sculpture in important ways. An economic design option that does not involve such 
changes is to provide additional information about the work of art that lessens the extent that it will be seen as a public bad. Art historians like Senie suggest this as a possible strategy. Part of the inspiration for this approach seems to be the observation that people confronted with a work of art they do not understand will sometimes try to interpret it to make it more understandable. ${ }^{22}$ Providing better information might, in this view, lead to a more positive understanding and appreciation of what the artist has constructed. Senie refers to this as fostering audience acceptance by giving puzzled viewers a meaningful answer to the "what is it?" question [Senie, 1992a] ${ }^{23}$ In terms of Figure 1, this strategy, if successful, would have the effect of shifting up the dd curve, thereby in turn raising the bc curve, representing net community benefits. We will not give this potential remedy of modifying tastes additional discussion, since it strikes us as the least potentially successful of the four alternative strategies we have identified.

\section{But Is The "Cure" Worse Than The "Disease"?}

Our argument thus far has been that, for the specific example of public sculpture, there may be economic design strategies available that can alter the public bad component of these mixed public goods/public bads. An art aficionado might find this mindset and suggested "minimize the bad" strategy troubling for (at least) the following reason. The provision of art can be viewed as having functions not well or completely described by their current effect on the utility of current viewers. There are many dimensions to this assertion. One is that what strikes viewers as discomfiting "today" may be seen as seminal and magnificent "tomorrow." A second dimension is that generating controversy may arguably be a productive function of art. A third dimension suggests more generally that arts might be in part about things like "communication (as Tolstoy suggests), or ...[be]... more like education...[so] ...'utility' does not cover the whole story. There has even been work in neuroscience that suggests that arts stimulate a different part of the brain from the part touched by most consumption." ${ }^{4}$

We do not deny the possible merits of these and related assertions. In response, we would point out that:

1. We are proposing a set of economic design propositions about the production of the "public bad" portion of mixed public goods and public bads. Knowledge of these production characteristics can aid in more informed decision-making about the provision of public art.

2. Public art is typically supported and financed wholly or in part by public funds. The normative desirability of public funding for public art rests on a clear understanding of what the social rationale or "public purpose" is for providing such funding. Coming to grips with that issue would provide the needed insight into the correctness-or-not of assertions such as "controversy in (public) art is socially desirable." Certain conceptions of the social purpose of publicly financing public art might support the desirability of minimizing the "public bad" component, ${ }^{25}$ while other conceptions might reject it. ${ }^{26}$ 


\section{CONCLUSION}

This paper has attempted to document that, for one class of mixed public goods and bads, there are economic design options that affect the good/bad "mix." We view our analysis as illuminating the "production function" of bads versus goods in the case of public sculpture.

A question this analysis suggests is whether other mixed public goods and bads are also amenable to design choices that change the good/bad mix. Consider the example of the reintroduction of wolf populations into some US national parks. Some observers view the presence of wolves as a public good, while other potential park users are somewhere between discomfited and terrorized by the animals' presence. At least at first blush, there seem to be far fewer design options here for preserving the good and minimizing the bad; either the wolves are introduced, or they are not. Is this characterization correct, or are there subtle ways of minimizing the alleged bads? Are other mixed public good/public bad examples more like the sculpture case, or instead instances with few-to-no design options? These seem interesting questions for future research.

\section{NOTES}

In the course of writing this paper, the authors benefited from conversations with and comments from Bryan Boulier, David George, David Greenberg, David Grier, Ken Koford, Thomas C. Leonard, John Lowe, David Levy, Don Parsons, Herman Stekler, seminar participants at George Mason University, and several anonymous referees. The authors are solely responsible for remaining errors.

1. Useful discussions of sculpture controversies in the United States include Cordes and Goldfarb [1996], Rushton [2000], and Tepper [2000]. None of these focus on design feature questions that are the subject of this paper.

2. A Serra sculpture was installed a number of years ago on the Princeton campus. A Princeton newsletter for alumni [Princeton, 2000] described Serra as "(W)idely considered to be the most important sculptor of the late $20^{\text {th }}$ century...". While not every knowledgeable observer would agree, the statement testifies to Serra's prominence. A Serra is installed in a very prominent location in Washington, D. C.'s National Gallery of Art. An informative New Yorker profile of Serra notes in its subtitle that "his art is still overwhelming." [Tomkins, 2002, p.52]. The Frank Gehry-designed Guggenheim Museum in Bilbao, Spain has been a major displayer of Serra sculpture (for an analysis of a major Serra retrospective at that museum, see D'Souza and Donough, [2000]). A new permanent installation of a large number of Serras at the Guggenheim Bilbao drew from the N.Y. Times reviewer the statement that the "installation is one of the great works of the past half-century, the culmination of a remarkable fruition in Mr. Serra's career.” [Kimmelman, 2005a, p. E-1]. For a history of sculpture developments in the second half of the $20^{\text {th }}$ century, see Causey [1998].

3. The debates leading to the removal have been described by Glazer [1992] as follows:

The art establishment rallied in defense of Tilted Arc. The long list of those who spoke in favor ...at a public hearing is impressive: curators from leading museums, professors of art history, art critics and art dealers, leading architects, painters, sculptors, composers. Those speaking against could not have been more different: judges, federal employees, union officials, area residents. The confrontation could fairly be summed up as the world of art against the people [Glazer, 1992: 15-16].

Senie has a different view of the campaign to get Tilted Arc removed, putting a great deal of the onus on William Diamond, appointed as GSA regional administrator for New York in 1984. Under 
Diamond, "complaints about the sculpture were orchestrated into a full-scale attack" [Senie, 2002, 27]. This orchestration included the way he managed the "so-called" [Senie,2002, 28] public hearing mentioned by Glazer in the quote above.

4. The term "seemed" in "seemed to curtail movement" is used because Senie [2002, 96] argues that Serra had actually studied pre-Tilted Arc pedestrian patterns in the Plaza, and designed Tilted Arc so it did not interfere with existing patterns. The pre-existing fountain itself limited the paths pedestrians could take across the Plaza. This line of argument, while certainly worth taking seriously--Senie's book is a very thoughtful, and well-done treatment of the controversy and issues surrounding it-seems implausible on two grounds. First, if one views the photos of the plaza from above (Senie [2002 Figures 2, 29,34] and photos in American Council for the Arts, [1989]), it is quite clear that someone walking around the fountain would have his or her access across the Plaza additionally impeded by Tilted Arc. Second, what we know from Senie [2002], Glazer [1992] and Tomkins [2002] about Serra's personality and mindset make it highly implausible that he would have cared about whether or not he was inconveniencing pedestrians. Indeed, some of the arguments later in this paper suggest he might have considered such inconveniencing a desirable feature of Tilted Arc.

5. Unfortunately, while Senie's book is outstanding, she fails to cite and discuss Glazer, a major contributor to public policy discussions as far back as his famous book with Moynihan [1963]. Thus, she does not address Glazer's views about Serra's apparent motivation.

6. Senie also describes Serra's changing statements of what he had been up to as the controversy continued [Senie, 2002,80]. One telling statement in 1991, after the sculpture had been removed, suggests that, rather than criticizing the existing architecture (as Glazer claimed), Serra was criticizing the entire governmental and corporate structure: "In such cases it is necessary to work in opposition to the constraints of the context, so the work cannot be read as an affirmation of questionable ideologies and political power. I am not interested in art as affirmation or complicity." [Senie, 2002, 81, quoting Serra]

7. Public controversy about Serra sculptures is not restricted to Tilted Arc. Senie [2002, 12-17] has a 5-page section on earlier Serra controversies.

8. If Serra was trying to irritate viewers, it was apparently part of a larger purpose, to criticize the architecture his sculpture "embellished."(or, in the Senie interpretation, to criticize the entire social system). A case cited in Newsweek [2002] involves a sculptor in Florida whose only aim appears to have been to irritate. Apparently annoyed at his neighbors, he installed a large sculpture of naked buttocks in his front yard, which "mooned" the neighborhood. The local sheriff remarked "It's become a local curiosity" [Newsweek, May 27, 2002]. While this is a ridiculous extreme case, it does illustrate the idea that sculpture can in fact be designed to annoy those who see it. For a case of a monumental "backyard" sculpture which, while not intended to irritate neighbors, did so anyway, see Gootman [2001]. Gootman describes the case of a 40 foot tall two ton welded steel sculpture of a heron. After a "nasty three year court battle," the NewYork State Supreme Court ruled that the sculpture had to be removed.

9. The process that led to selection of Serra's Tilted Arc is filled with ironies, well-described by Senie. The GSA review process had "divided but negative" views of the Serra sculpture's appropriateness . "Nevertheless, despite strong personal reservations, key members of the GSA staff approved Serra's design. At the time this apparently seemed like the course of least resistance." [Senie, 2002, 23]. Senie makes the broader point that Serra already had a track record of producing art hard for the public to understand, art that generated controversy: "he was a known artist with a history of controversy surrounding his public pieces. Both the nature of his sculpture and the public and critical responses were familiar to those involved. What, then, led them to proceed with this choice?" [Senie,2002,19].

10. A commenter on an earlier draft of this paper argued that "the selection process for public art has already been modified along the lines suggested here to include more community representation." We do not deny this: our aim is just to identify this strategy as possibly helping to lessen controversy. We have not tried--and it is beyond the scope of this paper--to gauge the degree of actual community participation in various public sculpture programs since 1989. We note in passing, however, Senie's assertion that the post-Tilted Arc redesign of Federal Plaza did not involve "more community representation" in the selection of the designer, landscape architect Marsha Schwartz: "Schwartz's services were folded into the architecture budget, thereby obviating the need for a formal art-selection process. The GSA substituted Schwartz's work for Serra's in a unilateral manner, much as it had removed Tilted Arc." [Senie, 2002, 98]. There are, of course, any number of important issues, beyond the scope 
of this paper, associated with whether to include "community participation" in the selection process. These include the following. First, if community representatives are to have an explicit say in the selection process, how are individuals "representative of the community" to be selected, and what "credentials" should they have? A second issue is empirical: where such inclusion has been practiced, how has it actually worked to affect actual project choice?

11. For example, Charles Griswold [1986] observed that the VVM was "the most visited of all the memorials in Washington." He noted that his initial visit reduced him to "awed silence," and claimed that such reactions are "far from unique...among the many visitors to the VVM." [Griswold, 1986, p.688]

12. Griswold [1986, 718] has described the VVM selection process as follows. The design criteria for the memorial "were that the monument (1) be reflective and contemplative in character, (2) be harmonious with its site and surroundings, (3) provide for the inscription of the 58,000 who gave their life or remain missing, (4) make no political statement about the war, and (5) occupy two acres of land... The design competition was open to all United States citizens over eighteen years of age. The jury of seven internationally known architects and one writer/design critic was selected by the Vietnam Veterans Memorial Fund. A total of 1,421 entries were submitted to the competition. They were judged anonymously (identified to the jurors only by number). After deliberating, the jury unanimously recommended Lin's design to the eight directors of the Vietnam Veterans Memorial Fund, who in turn accepted the nomination unanimously. The proposal then had to go through the lengthy federal approval process."

13. We have only seen pictures of Tilted Arc, but one of us has seen Waxing Arc in person.

14. This quotation is from a referee's comment on an earlier draft of this paper.

15. A quite different kind of argument for making sculpture installations fixed-term rather than permanent rests on the idea that larger happenings in the world may cause the public to view particular sculptures differently and less favorably. An article by Geoffrey Fowler in the June 3, 2002 Wall Street Journal gives a number of cases where world events, such as September 11, had caused a severe change in the way a particular piece of public art was viewed. He cites the Irish art historian and critic Brian McAvera as arguing more generally that no piece of public art should be viewed as permanent; a five-year span would be appropriate. Part of McAvera's argument appears to be that very few art works turn out, with the "shifting of history," to be very good. Levinson [1998] has identified numerous instances in which once-accepted public sculpture memorials/monuments were overtaken by changes in historical views. See also Nicholson's [1998] review of Levinson.

16. An argument consistent with the bc curve rising - that is the net effect of making the installation beneficial-involves the dual claims of "diminishing marginal utility" to the art lover from viewing any work of art, combined with a claim of "rising marginal disutilty" of repeated viewings for those who dislike the work of art. Anyone who has returned to the same museum repeatedly over a short period to see the same painting will know that sooner or later the "utility-kick" declines substantially. If this is right, then a temporary installation may "cream off" the large utility gains for initial viewing, eliminating only the much smaller gains from the Nth repeat viewing. The argument for a rise in bc is reinforced by positing "rising marginal disutility" to those who find the sculpture to be a "public bad": the marginal irritation it generates grows, the more (longer) one has to confront it.

17. The Public Art Fund has a long history of organizing such exhibits. The Haring exhibit was organized in collaboration with Haring's estate and the Whitney Museum, with the cooperation of several New York city agencies and private firms. An exhibit brochure [Wilson,1997] describes the Fund as "a nonprofit arts organization supported in part with public funds from the New York State Council on the Arts, a state agency, the New York City Department of Cultural Affairs," and donations from private contributors.

18. The article goes on to comment that “Puppy' proves that outstanding contemporary artists can make work that speaks to a broad public. Mr. Koons has managed to turn ...one of modernism's more esoteric points of origin, into a crowd-pleaser."

19. Some kinds of public sculpture are arguably inappropriate for temporary or "traveling" installations: memorials typically imply and require permanence, and site-specific sculptures (those designed specifically for the site at which they are to be installed) are not meant to travel.

20. Why might a sculptor agree to undertake such a commission, knowing that the work would only be displayed for a short time? We inferred the following explanations from discussions by two sculptors doing temporary installations at George Washington University. (1) A temporary installation allowed one to use "less permanent" materials, which presented interesting artistic challenges. 
For example, one of the artists discussed his interest in seeing how the material would "weather" in the six months the sculpture was to be on display. (2) Winning such a commission is a sign of artistic accomplishment (just as winning a commission for a permanent installation is). (3) The sculpture becomes a permanent part of the sculptor's portfolio through the use of photographs and videos, backed up by design sketches. (4) The professor of sculpture had used the GW sculpture very effectively as a teaching tool, involving his sculpture students in its planning, actual construction, and installation.

21. The Christo example was suggested by an anonymous referee. A recent Christo and Jean-Claude installation was "The Gates" in New York's Central Park for 16 days in February 2005. "(S)affron-colored panels of nylon cloth would wave from ...free-standing structures along 23 miles of park walkways." [Wallach 2005,84$]$. The structures were steel rectangular blocks. "Over the past 40 years, Christo and Jean-Claude have created 18 monumental, ephemeral installations across the globe.” [Wallach, 2005,. 84]. This includes projects that wrapped the Reichstag (1995) and the Pont-Neuf (1985). Commenting on "The Gates," the New Yorker art critic Peter Schjeldahl noted that "Those who deplore 'The Gates' as ugly aren't wrong, just poor sports. The work's charm-free, synthetic orange hue...is something you would wear only in the woods during deer season, in order to avoid being shot. The proportions of the arches are graceless, and dogs alone esteem the clunky bases." [Schjeldahl, 2005, 30]. Clearly not everyone thinks this installation was a public good.

22. Senie [1992a] presents numerous examples in which people try to interpret a particular sculpture to give it understandable meaning. For instance, a proposed public sculpture by Joel Shapiro "became the object of furious debate when the public (or press) dubbed the innocuous-looking piece...the headless Gumby" [Senie,1992a, 240].The well-known "Chicago Picasso," which is actually "a conflated image of his wife Jacqueline and his pet Afghan," was interpreted by various passers-by as "a baboon, bird, phoenix, horse, sea horse, Afghan hound, nun, Barbra Streisand, and a Viking helmet." [Senie, 1992a, 239] "Most tellingly, one outspoken colonel when first confronting the "Chicago Picasso" suggested "If it is a bird or an animal, they ought to put in the zoo. If it is art, they ought to put it in the Art Institute." [Senie, 1992a, 243].

23. Art historians also present interesting art-historical reasons why the prevalent style of sculpture in the last half of the $20^{\text {th }}$ century lent itself to being "hard for the public to understand and appreciate." For example, Senie and Webster [1992] argue that the emergence of large-scale public sculpture in the ' 60 s could be interpreted as an attempt to ornament modern architecture "after the fact":

What made this development even more problematic in terms of public art was the abstract style practiced by the most important artists of the day, an artistic vocabulary difficult for most museum audiences, and completely foreign for large segments of the public who now had to contend with it in the spaces they used daily. In a museum it could be ignored; in a public space it clearly could not. [Senie and Webster, 1992, xiii-xiv]

Causey [1998] argues that:

In previous centuries sculpture had certain functions--votive, commemorative, didactic, decorative--which it has gradually lost. After the early decades of this century, when avant-garde sculptors abandoned the tradition of Rodin and reconstituted their art from the examples of Cubist painting and relief, twentieth century sculpture lost touch with the wider public....With the end of the Second World War sculptors were asking themselves what, in an age of abstraction, a commemorative art might be. Was public sculpture possible?..Sculptors have preferred inscrutability to compliance with the values of a world increasingly influenced by marketing and entertainment." [Causey, 1998, 10]

24. The quote is from an anonymous referee.

25. In an extensive discussion of public art in New York City, the New York Times [Kimmelman, 2005b] points out that Eleanor Heartney has argued that "public art might be good but not successful, or vice versa. 'Success,' as Ms. Heartney writes, no longer would only 'be measured using traditional criteria of conceptual clarity or aesthetic coherence.' Now it would also depend on how the public responded to, and used the art."

26. Consider a simple highly stylized example. Suppose it was concluded that government subsidization 
of sculpture projects was normatively justifiable only for cases where major stylistic and materials innovations of a sort not yielding salable sculpture was involved. (Ignore the issue of whether the body issuing awards could successfully "pick" winners and losers by this criterion). An analogy here is to the $\mathrm{R}$ and $\mathrm{D}$ argument that the government should subsidize basic research whose payoffs are not appropriable to the researchers. This underlying finding about what it is desirable to subsidize would have economic design implications with respect to some of the strategies we identified. For example, allowing "community participation" in the selection process for public art is likely to limit the innovative content of the art selected, so "community participation" looks less desirable. On the other hand, if the issue is promoting artistic innovation, it is not at all clear why the innovative projects need to be installed where the general public is forced to confront them. The innovation, after all, is meant to influence current and future artists. The social return from irritating the public seems at best far from obvious.

\section{REFERENCES}

American Council for the Arts. Public Art Public Controversy: The Tilted Arc on Trial. New York: ACA Books, 1989.

Causey, A. Sculpture Since 1945. Oxford: Oxford University Press, 1998.

Cordes, J. and Goldfarb, R. The Value of Public Art as Public Culture, in The Value of Culture: On the Relationship Between Economics and the Arts, edited by A. Klamer. Amsterdam: University of Amsterdam Press, 1996, 77-95.

D'Souza, A. and McDonough, T. Sculpture in the Space of Architecture. Art in America, February 2000, 84-89.

Fleming R. The Meaning of Place. The Public Interest, Winter 1982, 27-31.

Fowler, G. Expiration Dates for Art? World Events, Shifting Tastes Can Bring About the Removal of Once-Esteemed Public Sculpture. The Wall Street Journal, June 3, 2002, B-1.

Glazer, N. 'Subverting the Context': Public Space and Public Design. The Public Interest, Fall 1992, 321.

Gootman, E. Moving This Heron Required a Crane, and a Legal Battle. The New York Times July 11, 2001, A-17.

Griswold, C. The Vietnam Veterans Memorial and the Washington Mall: Philosophical Thoughts on Political Iconography. Critical Inquiry, Summer 1986, 688-719.

Kimmelman, M. Abstract Art's New World, Forged for All. The New York Times, June 7, 2005a, E-1, E-6.

. Risks and Rewards of Art in the Open. New York Times, Aug 19, 2005b, E-31.

Levinson, S. Written in Stone: Public Monuments in Changing Societies. Durham, N.C.: Duke University Press, 1998.

Lewis, J. Pleasingly Plump: Fernando Botero's Mirthful Sculpture. The Washington Post, Sept 26, 1996, C1.

Moynihan, D. and Glazer, N. Beyond the Melting Pot: The Negroes, Puerto Ricans, Jews, Italians, and Irish of New York City. Cambridge: MIT Press, 1963.

Newsweek. Perspectives. May 27, 2002.

Nicholson, D. Losing our Marbles: Monumental Disagreements. The Washington Post, Aug. $25,1998$.

Phillips, P. Temporality and Public Art, in Critical Issues in Public Art: Content, Context, and Controversy, edited by H. Senie and S. Webster. New York: Harper Collins, 1992, 295-304.

Everybody's Art: Long-term Supporters of Temporary Public Art. Public Art Review, Spring/ Summer 1994, 4-8.

Princeton. Serra's Arcs Shift Time and Space. Princeton (alumni newsletter published by the University's Office of Development Communications), Summer 2000, 7.

Rushton, M. Public Funding of Controversial Art. Journal of Cultural Economics, November 2000, 267282.

Schjeldahl, P. Gated. The New Yorker, February 28, 2005, 30-31.

Senie, H. Baboons, Pet Rocks, and Bomb Threats: Public Art and Public Perception, in Critical Issues in Public Art: Content, Context, and Controversy, edited by H. Senie and S. Webster. New York: Harper Collins, 1992a, 237-246.

. Contemporary Public Sculpture: Tradition, Transformation and Controversy. New York: 
Oxford University Press, 1992b.

. The Tilted Arc Controversy: Dangerous Precedent? Minneapolis: University of Minnesota Press, 2002.

Senie, H. and Webster, S. Introduction, in Critical Issues in Public Art: Content, Context, and Controversy, edited by H. Senie and S. Webster. New York: Harper Collins, 1992, xi-xvii.

Smith, R. Stretching Definitions of Outdoor Sculpture. The New York Times, July 28, 2000, B27, B29.

Stalker D. and Glymour, C. The Malignant Object: Thoughts on Public Sculpture. The Public Interest, Winter 1982, 3-21.

Tepper, S. Unfamiliar Objects in Familiar Places: The Public Response to Art-in-Culture. Cultural Policy, 2000, 283-316.

Tomkins, C. Man of Steel. The New Yorker, August 5, 2002, 52-63.

Valentine, P. Not Just a Matter of Taste. The Washington Post, June 21, 1995, B-3.

Vogel, C. A Steel Tree in Central Park? Well, Times Have Changed. The New York Times , February 27, 2002, A23.

Wallach, A. Christo Does Central Park. The Smithsonian, February 2005, 84-90.

Weyergraf-Serra, C. and Buskirk, M. The Destruction of Tilted Arc: Documents. Cambridge: the MIT Press, 1991.

Wilson, L. Keith Haring. Museums New York: Special Edition (Pamphlet for the Whitney Museum Haring Show). Summer 1997. 